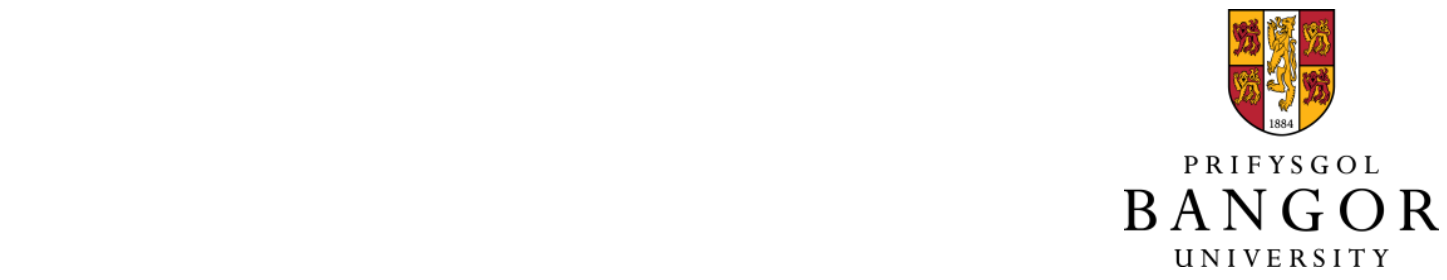

Indirect oxidative bioleaching of a polymetallic black schist sulfide ore

Pakostova, Eva; Grail, Barry; Johnson, David

\title{
Minerals Engineering
}

DOI:

10.1016/j.mineng.2016.08.028

Published: 15/05/2017

Peer reviewed version

Cyswllt i'r cyhoeddiad / Link to publication

Dyfyniad o'r fersiwn a gyhoeddwyd / Citation for published version (APA):

Pakostova, E., Grail, B., \& Johnson, D. (2017). Indirect oxidative bioleaching of a polymetallic black schist sulfide ore. Minerals Engineering, 106, 102-107.

https://doi.org/10.1016/j.mineng.2016.08.028

\section{Hawliau Cyffredinol / General rights}

Copyright and moral rights for the publications made accessible in the public portal are retained by the authors and/or other copyright owners and it is a condition of accessing publications that users recognise and abide by the legal requirements associated with these rights.

- Users may download and print one copy of any publication from the public portal for the purpose of private study or research.

- You may not further distribute the material or use it for any profit-making activity or commercial gain

- You may freely distribute the URL identifying the publication in the public portal ?

Take down policy

If you believe that this document breaches copyright please contact us providing details, and we will remove access to the work immediately and investigate your claim. 


\title{
Indirect oxidative bioleaching of a polymetallic black schist sulfide ore
}

\author{
Eva Pakostova*, Barry M. Grail and D. Barrie Johnson
}

College of Natural Sciences, Bangor University, Bangor, LL57 2UW, UK

*Correspondence: e-mail, e.pakostova@bangor.ac.uk;

Tel: +44-(0)1248-382358. Fax +44 1247370731 


\section{Abstract}

Biomining of base and precious metal-containing sulfidic ores and concentrates is an important global biotechnology. Currently, mineral bio-processing is carried out in dumps, heaps and stirred tanks located on the land surface. An alternative approach, "deep in situ biomining", would solubilise target metals from fractured ore bodies buried deep $(>1 \mathrm{~km})$ underground, using a microbially-generated acidic, ferric iron-rich lixiviant. Pregnant leach solutions (PLS) generated are pumped to the land surface where metals are extracted and recovered, ferric iron regenerated in a bioreactor and the oxidised lixiviant re-injected underground. To examine the feasibility of using an indirect bioleaching approach to extract metals from an ore body, a laboratory test was carried out using a polymetallic sulfidic black schist ore (from Talvivaara, Finland) in a non-aerated column reactor, maintained at $30^{\circ} \mathrm{C}$ at atmospheric pressure. Following an initial acid leaching phase (using $100 \mathrm{mM}$ sulfuric acid) the ore was subjected to ferric iron-catalysed oxidative dissolution using a lixiviant generated in a laboratory-scale ferric iron-generating bioreactor (FIGB). During the 16 week time course of the experiment, $93 \%$ of manganese, $88 \%$ of cobalt, $79 \%$ of nickel, $75 \%$ of iron, $75 \%$ of zinc and $55 \%$ of copper present in the ore was extracted. The planktonic microbial populations in the FIGB and those in the PLS were similar, and dominated by Leptospirillum ferriphilum, ironoxidising Acidithiobacillus spp. and the archaeon Ferroplasma acidophilum.

\section{Introduction}

Using the microorganisms to accelerate the oxidative dissolution of sulfidic minerals in ores and minerals ("biomining"), has developed into an global biotechnology for extracting and facilitating the recovery of copper and gold, and to a lesser extent of cobalt, nickel and zinc (Rawlings and Johnson, 2007). Although still a niche technology, it has the potential to be used in a variety of contexts where conventional mineral processing is not economically or environmentally feasible, such as low grade ("run of mine") and polymetallic ores, and those 
with high arsenic contents (Brierley and Brierley, 2001). Since readily accessible, high-grade metal ores are becoming depleted, and demands for base and precious metals are increasing, there is a need to find an economical way to recover metals from materials that are currently perceived as being inaccessible, for example due to their placement deep ( $>1 \mathrm{~km}$ ) below the land surface.

Conventional biomining is carried out in dumps, heaps and stirred tanks (Brierley, 2008). Another approach, used both historically and in more recent times to extract additional uranium from otherwise worked out mines, is to use an in situ approach, whereby underground mines are periodically flooded to facilitate the microbially-assisted solubilisation of target metals which are subsequently recovered from the pregnant leach solutions (PLS). Uranium is currently being extracted from shallow aquifers using an in situ approach, in various parts of the world (Mudd, 2001), though in these situations the "bio" component is probably of minor significance. The proposal to develop and test a "deep in situ biomining protocol",is the remit of the European Union Horizon 2020 project "BioMOre" (www.biomore.info). Here the objective is to bioleach base metal ore deposits located at far greater depths (>1 km), where conditions, such as elevated temperatures and pressures, would be much different from those encountered hitherto in in situ operations. In addition, ensuring the supply of oxygen and carbon dioxide, which are both essential for growth and oxidation of iron and sulfur by biomining microorganisms, to fractured ore bodies at these depths would not be pragmatic. To get around this problem, an indirect bioleaching protocol has been suggested (Johnson, 2015). This involves delivering an acidic, ferric iron-rich lixiviant, generated in bioreactors located at the land surface, to the ore body where it flows through channels opened by hydraulic fracturing, oxidising sulfide minerals and solubilising metals such as copper. The PLS generated is reduced (ferrous iron-rich), rather than oxidised as in conventional biomining, and is pumped to the land surface where the soluble copper is removed, e.g. using sulfide precipitation or solvent extraction and electrowinning. Ferrous iron in the raffinate solution is then re-oxidised to ferric in the bioreactor, and the regenerated lixiviant recirculated into the ore body. Indirect mineral bioleaching has been described elsewhere (Schippers and 
Sand, 1999; Rawlings, 2004) and has the advantage of separating (chemical) mineral oxidation from (biological) ferrous iron oxidation, allowing conditions (such as temperature) for each to be optimised separately. Also, since ferric iron-catalysed oxidation of sulfide minerals is independent of molecular oxygen, the absence of oxygen in lixiviants percolating through a deep-buried ore body would not preclude the extraction of base metals, though it would mean that there would be no regeneration of ferric iron in situ, in contrast to biomining carried out in aerated bioheaps and stirred tanks.

The polymetallic sulfidic black schist which outcrops at the land surface at Talvivaara, Finland, has been processed using heap bioleaching during the past decade (Riekkola-Vanhanen, 2013), though recent problems at the site have caused a curtailment in mining (Bedford, 2015). The ore body contains of quartz (25\%), aluminium silicates (38\%), iron sulfides (16\%), graphite (10\%), magnesium-iron silicates $(8 \%)$ and sphalerite $(\mathrm{ZnS})$-pentlandite $\left((\mathrm{Fe}, \mathrm{Ni})_{9} \mathrm{~S}_{8}\right)$-violarite $\left(\mathrm{FeNi}_{2} \mathrm{~S}_{4}\right)(3.2 \%)$ (Loukola-Ruskeeniemi, 1996). The major base metals present are Fe (10 $13 \%), \mathrm{Zn},(0.2-0.5 \%)$, Ni (0.2 - 0.3\%), Cu (0.1 - 0.6\%) and Co (0.02-0.04\%) (Puhakka et al., 2007; Dopson et al., 2008; Wakeman et al., 2008; Halinen et al., 2009), with nickel being the primary metal targeted for extraction and recovery. This is deported in pentlandite and violarite, pyrite $\left(\mathrm{FeS}_{2}\right)$ and pyrrhotite $\left(\mathrm{Fe}_{(1-x)} \mathrm{S}\right)$. Attempts to produce a high-grade nickel concentrate from the ore were not successful because of its graphite content, and heap bioleaching is carried out using ground ore particles, agglomerated using sulfuric acid. Several independent preliminary studies, carried out in aerated columns, had suggested that Talvivaara ore was amenable to oxidative dissolution in aerated, irrigated heaps (Puhakka and Tuovinen, 1986a-c; Riekkola-Vanhanen and Heimala, 1999; Wakeman et al., 2008; Halinen et al., 2009). The exothermic nature of pyrrhotite oxidation, in particular, maintains elevated temperatures (up to $\sim 80^{\circ} \mathrm{C}$ ) in the insulated heaps, supporting the activities of thermophilic as well as mesophilic biomining microorganisms (Riekkola-Vanhanen, 2013). Dopson et al. (2008), however, reported that bioleaching the ore at extremely low pH ( 1.5) resulted in extensive solubilisation of silicon (by acid dissolution of aluminosilicates) which greatly increased the viscosity of percolating liquors and impeded the bioleaching process. 


\section{Materials and Methods}

\subsection{Ferric iron-generating bioreactor (FIGB)}

A laboratory-scale biofilm reactor was commissioned to generate an acidic ferric iron lixiviant. A $2 \mathrm{~L}$ glass reactor vessel fitted with a stainless steel top plate and various inserts (Electrolab, U.K.) was filled sequentially with a layer ( $2 \mathrm{~cm}$ depth) of acid washed gravel, followed by $13 \mathrm{~cm}$ of acid-washed porous glass beads $(8 \mathrm{~mm}$ diameter; Poraver-Dennert $\mathrm{GmbH}$, Germany) and a second $2 \mathrm{~cm}$ layer of gravel. Six hundred millilitres of a solution containing basal salts and trace elements (Ňancucheo et al., 2016), adjusted to pH 1.6 with sulfuric acid, was added and the reactor vessel sterilised by autoclaving. After cooling, a filter-sterilised solution of ferrous sulfate was added to the vessel, to give a final $\mathrm{Fe}^{2+}$ concentration of $\sim 50$ $\mathrm{mM}$. The reactor was then inoculated with 14 strains of acidophilic bacteria and archaea, commonly or occasionally found in biomining operations and maintained in the Acidophile Culture Collection at Bangor University, UK (Table 1). These acidophiles had been pre-grown in appropriate liquid media (ferrous iron or elemental sulfur for obligately autotrophic species; yeast extract-amended media for facultatively autotrophic and obligately heterotrophic species) and at suitable temperatures (30을 $\mathrm{C}$ for mesophilic species and $40^{\circ} \mathrm{C}$ for thermotolerant species). The temperature of the FIGB was maintained at $35^{\circ} \mathrm{C}$ using a FerMac 240 temperature controller (Electrolab) and the bioreactor was aerated (at $\sim 1 \mathrm{~L} / \mathrm{min}$ ) with filtersterilised air. When all of the ferrous iron had been oxidised, the bioreactor was switched to continuous flow mode, using a slightly more acidic $(\mathrm{pH} 1.5)$ influent liquor (to minimise jarosite precipitation) and amended also with $100 \mathrm{mM}$ magnesium sulfate to increase the buffering afforded by the sulfate/bisulfate couple. Flow rates into and out of the bioreactor vessel varied between 55 and $400 \mathrm{~mL} / \mathrm{h}$, equivalent to hydraulic retention times (HRTs) of between 33 and 5 hours. Effluent liquors generated by the FIGB where $>99 \%$ of the ferrous iron had been oxidised to ferric, were collected and used as lixiviants for indirect bioleaching of Talvivaara ore, as described below. 


\subsection{Acid leaching and indirect bioleaching of Talvivaara ore}

A column bioreactor, comprising a Perspex tube $(32 \mathrm{~cm}$ long and $7.5 \mathrm{~cm}$ diameter $)$ filled with $1.375 \mathrm{~kg}$ of non-sterile polymetallic ore $(2.0-6.7 \mathrm{~mm}$ diameter) provided by the Talvivaara Mining Company, was set up in a temperature-controlled $\left(30^{\circ} \mathrm{C}+/-2^{\circ} \mathrm{C}\right)$ room. Non-sterile sulfuric acid (100 mM; $600 \mathrm{~mL}$ ) was added to the column, and after three days the column was connected to $5 \mathrm{~L}$ inflow and outflow vessels and fresh $100 \mathrm{mM}$ sulfuric acid pumped through continuously for a further 10 days, at a constant flow rate of $55 \mathrm{~mL} / \mathrm{h}$ (equivalent to a HRT of 11 hours). Following this, this influent liquor was changed to the ferric iron lixiviant generated by the FIGB, which contained $\sim 50 \mathrm{mM}$ ferric iron, and had a $\mathrm{pH}$ of $\sim 1.8$. The same flow rate was maintained as during the acid leaching phase, and indirect bioleaching of the Talvivaara ore continued for a further 103 days. The column reactor was not aerated in any stage of the experiment. Samples of liquids draining the column reactor were withdrawn at regular intervals to determine $\mathrm{pH}, E_{\mathrm{H}}$, concentrations of dissolved metals and silicon, and also for microbiological and molecular biological analysis.

\subsection{Chemical and Geochemical analyses}

Concentrations of ferrous iron in the effluent liquors were determined using the Ferrozine colorimetric assay (Stookey, 1970) and total iron by the same assay after reducing soluble ferric iron to ferrous iron with ascorbic acid. Ferric iron was determined from differences in total and ferrous iron concentrations. Concentrations of transition metals ( $\mathrm{Co}, \mathrm{Ni}, \mathrm{Zn}, \mathrm{Co}$, and $\mathrm{Mn}$ ) were measured by ion chromatography (IC), using a Dionex DX-320 ion chromatograph attached to an Ion Pac CS5A column and an AD25 absorbance detector (Dionex, Sunnyvale, CA), and analysed using Chromeleon software (version 6.40) (Wakeman et al., 2008; Ňancucheo and Johnson, 2012). The $\mathrm{pH}$ values of leachates were measured using a pHase combination glass electrode, and redox potentials (adjusted to be relative to a standard 
hydrogen electrode, $E_{H}$ values) using a combination platinum silver/silver chloride electrode (VWR International, UK). Both electrodes were coupled to an Accumet pH/redox meter 50.

The transition metal contents of the Talvivaara ore were obtained by fine-grinding of $100 \mathrm{~g}$ of a representative sample, dissolving replicate $1 \mathrm{~g}$ samples in $4 \mathrm{~mL}$ of aqua regia (a mixture of concentrated nitric and hydrochloric acid, one part of the former to three parts of the latter by volume), diluting and measuring soluble metals as described above.

\subsection{Microbiological and biomolecular analyses}

Planktonic microorganisms in lixiviant and leachate samples were enumerated using a Thoma counting chamber and a Leitz Wetzlar 766200 (Germany) phase contrast microscope, at $\times 400$ magnification. Cultivatable bacteria and archaea were detected by plating samples onto selective solid overlay media (Johnson and Hallberg, 2007). Plates were incubated at both $30^{\circ}$ (for mesophiles) and $45^{\circ} \mathrm{C}$ (for thermo-tolerant species) for 10 days, and isolates identified on the basis of their colony and cellular morphologies (Johnson et al., 2005) and also, where necessary, from the T-RF analysls of their 16S rRNA genes (Kay et al., 2013). Planktonic microbial populations were also analysed using terminal restriction enzyme fragment length polymorphism (T-RFLP), using protocols described elsewhere (Kay et al., 2013). Two restriction enzymes were used to analyse both bacterial (Haelll and Cfol), and archaeal (Cfol and Alul) populations.

\section{Results}

\subsection{Generation of acidic ferric iron lixiviants by the FIGB}

Ferric iron-rich lixiviants were readily generated by the FIGB following the build-up of biomass on the porous glass beads. With HRTs of 10 hours or more, $>99 \%$ of the ferrous iron in the influent was oxidised to ferric, though this declined at higher flow rates (e.g. only $~ 55 \%$ of the iron was oxidised with a HRT of 5 hours). Only solutions in which $>99 \%$ of the ferrous iron had 
been oxidised were used as lixiviants for ore dissolution, and these had a $\mathrm{pH}$ and $E_{\mathrm{H}}$ values of $\sim 1.8$ and $+880 \mathrm{mV}$, respectively.

\subsection{Acid dissolution of Talvivaara ore}

Significant amounts of ferrous iron, but little ferric iron, was leached from the Talvivarra ore by sulfuric acid (Figs. 1a and 1b). Redox potentials of leachates fell from $+560 \mathrm{mV}$ to $+370 \mathrm{mV}$ (Fig. 1c), the relatively low values reflecting the fact that the sulfide/sulfate couple was important in dictating $E_{\mathrm{H}}$ values during this phase (hydrogen sulfide was detected, presumably resulting from acid dissolution of pyrrhotite). The $\mathrm{pH}$ values of the effluent liquors were always higher than that of the sulfuric acid influent liquor $(\mathrm{pH} \sim 1.0)$ and decreased from about 1.8 to about 1.5 as the acid leaching progressed. Many of the transition metals present in the ore were found in acid leachates, the exception being copper, which was always below the level of detection. The total amounts of metals leached from the ore using sulfuric acid (as percentage values of those present) were $10 \% \mathrm{Fe}(16 \mathrm{~g}), 66 \% \mathrm{Mn}(7.5 \mathrm{~g}), 4 \% \mathrm{Zn}(0.3 \mathrm{~g}), 11 \%$ $\mathrm{Ni}(0.3 \mathrm{~g})$, and $2 \%$ Co $(0.01 \mathrm{~g})$ (Fig. 2). In addition, $5.1 \mathrm{~g}$ of silicon was leached from the ore during the acid leaching phase (Fig. 3).

\subsection{Indirect bioleaching of Talvivaara ore}

Over $90 \%$ of the ferric iron present in the lixiviant generated by the FIGB was reduced to ferrous in the early phase of indirect bioleaching of the Talvivaara ore (Figs. 1a and 1b). Thereafter the concentration of ferrous iron in the ore leachates decreased while those of ferric iron increased. This was paralleled by a gradual increase in redox potentials, from +600 to $+690 \mathrm{mV}$ (Fig. 1c). Throughout this phase the concentrations of soluble ferrous iron in the leachates exceeded those of the ferric iron present in the lixiviant as a result of the ongoing oxidative dissolution of iron-containing sulfide minerals. The $\mathrm{pH}$ of the percolating liquor increased significantly during the early stage of indirect bioleaching (from $\mathrm{pH} 1.8$ to 2.6) and this was accompanied by a visible accumulation of secondary ferric iron precipitates on the 
ore particle surfaces. As time progressed, the $\mathrm{pH}$ of the ore leachate declined, reaching $\mathrm{pH}$ 1.9 by the end of the experiment (Fig. 1c).

Cumulative percentages of metals ( $\mathrm{Fe}, \mathrm{Mn}, \mathrm{Zn}, \mathrm{Cu}, \mathrm{Ni}$, and $\mathrm{Co}$ ) leached from the polymetallic ore are shown in Figure 2. Indirect bioleaching resulted in further extraction of base metals from the ore: $65 \%$ for iron ( $103.4 \mathrm{~g}), 27 \%$ for manganese $(3.0 \mathrm{~g}), 71 \%$ for zinc $(5.2 \mathrm{~g}), 55 \%$ for copper ( $2.4 \mathrm{~g}), 67 \%$ for nickel $(1.9 \mathrm{~g})$, and $86 \%$ for cobalt $(0.5 \mathrm{~g})$. While leaching of manganese and copper essentially came to a halt after about 60 days, other base metals (nickel, cobalt, iron and zinc) continued to be extracted over the entire timeframe of the experiment. After 116 days of combined acid and indirect bioleaching, total metal extraction was $75 \%$ for $\mathrm{Fe}, 93 \%$ for $\mathrm{Mn}, 75 \%$ for $\mathrm{Zn}, 55 \%$ for $\mathrm{Cu}, 79 \%$ for $\mathrm{Ni}$, and $88 \%$ for Co. Silicon (21.8 g) was also leached from the ore (Fig. 3), with a maximum recorded concentration of $0.5 \mathrm{~g} \mathrm{~L}^{-1}$. 


\subsection{Microbial dynamics}

Numbers of planktonic microorganisms in the lixiviant produced by the FIGB varied between $1-3 \times 10^{7} \mathrm{~mL}^{-1}$, while those present in the ore leachates were more variable $\left(1-10 \times 10^{7} \mathrm{~mL}^{-}\right.$ ${ }^{1}$ ). Only five of the fourteen acidophiles used to inoculate the FIGB were isolated from lixiviant and ore leachate samples (Table 2). These included both mesophilic (At. ferrooxidans and At. ferridurans; their separate identities confirmed by sequencing their 16S rRNA genes) and thermo-tolerant (At. caldus, L. ferriphilum and Sb. thermosulfidooxidans) species. In general, similar trends were observed in terms of isolates obtained from lixiviants and leachates, with the notable exception that $A t$. caldus was more frequently isolated from ore leachates than FIGB lixiviant liquors. The same bacteria were also detected using semi-qualitative T-RFLP analysis, though At. ferrooxidans and At. ferridurans could not be distinguished separately with the restriction enzymes used (Fig. 4). In addition, two other mesophilic acidophiles (the iron-oxidising autotroph $L$. ferrooxidans and the obligate heterotroph $A$. cryptum SJH) were also detected by T-RFLP, though as relatively minor members of the microbial communities. T-RFLP analysis indicated that the most abundant bacterium in the FIGB lixiviants was L. ferriphilum, accounting on average for $58 \%$ of the total bacterial population, while in the ore leachates the iron-oxidizing autotrophic Acidithiobacillus spp. were more abundant ( $50 \%$ of total bacteria) than L. ferriphilum (43\%, relative abundance) and that $A$. cryptum, Sb. thermosulfidooxidans, and At. caldus each accounted for $0-10 \%$ of the bacterial populations (Fig. 4). Only Fp. acidophilum, out of the two inoculated archaea, was detected by T-RFLP analyses (data not shown). Attempts both to isolate acidophiles and to amplify and analyse microbial genes from liquid samples during the acid leaching phase were unsuccessful.

\section{Discussion}

In situ bioleaching of deep buried ore bodies is a potential important development for metal mining in the $21^{\text {st }}$ century. Advantages to in situ biomining include lower processing costs by 
eliminating the need to haul, crush and grind ore. In addition, its environmental impact is smaller since there is no need for surface storage and disposal of potentially hazardous mine wastes; typically $\sim 99 \%$ of ore material is waste. In deep in situ biomining, most of the ore body remains underground. In contrast to pyrometallurgy/smelting, relatively little $\mathrm{CO}_{2}$ would be produced by deep in situ bioleaching (Johnson, 2015). The process would necessarily operate by indirect bioleaching, using acidic ferric iron-rich lixiviants generated in bioreactors located at the land surface which would allow access of the acidophiles to sufficient oxygen (to promote iron oxidation) and carbon dioxide (for cell growth), as well as avoiding the high pressures which would exist within a deep-buried ore body. The experiment described in the current report was designed to mimic conditions in a deep in situ biomine, with the notable exception that both components of the experimental system (the FIGB and the ore column) operated at atmospheric pressure.

The polymetallic ore was subjected to a two-stage leaching process, the first with sulfuric acid (primarily to remove acid-labile gangue minerals) and the second with an acidic ferric iron-rich lixiviant. Acid leaching solubilised significant concentrations of some, though not all, of the base metals present in the ore. However, much more, and a greater variety of metals, was leached with the microbially-generated lixiviant. In contrast to previous columns leaching tests with Talvivaara ore, where the columns have been actively aerated to promote strongly oxidising conditions, the column in this test was not aerated. Some oxygen would be present in the FIGB lixiviants, but this would have been anticipated to be rapidly consumed in the ore column by bacteria oxidising both ferrous iron and reduced sulfur generated by ferric ironcatalysed dissolution of the sulfide minerals present. Although concentrations of dissolved oxygen were not measured, the fact that redox potentials were far less positive in liquors pumped out of the column compared to those that were pumped in (especially during early period of indirect bioleaching) reflecting the predominance of ferrous rather than ferric iron, strongly suggests that oxygen consumption in the column was extensive. Even with a pre-acid leaching phase, the $\mathrm{pH}$ of the percolating liquors increased during indirect bioleaching, 
causing some precipitation of secondary ferric iron minerals (most probably jarosites), which would have probably negatively impacted mineral dissolution both by forming passivation layers and by removing the soluble ferric iron oxidant.

The percentages of base metals extracted by indirect bioleaching in the current experiment compare favourably with those reported previously in aerated columns. The latter were summarised by Puhakka et al. (2007) to be $57-92 \%$ for Ni, $60-80 \%$ for $\mathrm{Zn}, 12-100 \%$ for Cu, and 14 - 65\% for Co. Riekkola-Vanhanen and Heimala (1999) had previously carried out a long-term ( 300 days) ore column test which extracted $92 \%$ of $\mathrm{Ni}, 80 \%$ of $\mathrm{Zn}, 66 \%$ of $\mathrm{Cu}$ and $65 \%$ of Co from the polymetallic Talvivaara ore. The current experiment, carried out under a far shorter (116 days) period of time, extracted $79 \%$ of the nickel present (the main target metal at the Talvivaara mine) and $75 \%$ of the zinc, $55 \%$ of the copper and $88 \%$ of the cobalt.

Another potential advantage of indirect bioleaching of this ore was that less silicon was solubilised than in some previous reports. The dissolution of silicate minerals brings silicon into solution, which can increase the leach liquor viscosity, form diffusion barriers and lower metal extraction. Solution $\mathrm{pH}$, though not temperature has a significant effect on silicate dissolution (Dopson et al., 2008). Halinen et al. (2009) and Dopson et al. (2008) reported problems with sample filtration due to amorphous gelatinous silica caused by a high $\mathrm{Si}$ concentrations present in $\mathrm{pH} 1.5$ leach solutions. The maximum Si concentration reported by Halinen et al. (2009) was $1.7 \mathrm{~g} \mathrm{~L}^{-1}$, while $3.0 \mathrm{~g} \mathrm{~L}^{-1}$ of silicon was reported by Dopson et al. (2008). The concentrations of silicon found in leachates in the present study (a maximum of $0.5 \mathrm{~g} \mathrm{~L}^{-1}$, found at the end of the acid leaching phase when the $\mathrm{pH}$ reached its minimal value of 1.5 ) were considerably lower, and avoided the viscosity and related problems reported elsewhere.

The apparent absence of microorganisms during acid leaching of the polymetallic ore suggests a zero biological input during that phase. In contrast, acidophilic bacteria and archaea had a very significant role in indirect leaching. Most of the bacteria used to inoculate the FIGB were not detected subsequently, and the dominant organisms comprised a narrow 
range of acidophilic microorganisms. No major time-related changes in the microbial populations, in either the FIGB or the ore column, were observed over the course of the leaching experiment. While most of the acidophiles would be anticipated to be retained in biofilms attached to the porous glass beads in the FIGB, the fact that some were continuously inputted into the column reactor may have impacted the dynamics of ore dissolution.

As would be anticipated, most of the bacteria in lixiviants generated by the FIGB were ironoxidising acidophiles, as ferrous iron was the only electron donor present. Interestingly, At. caldus, a bacterium that does not oxidise iron but uses elemental and reduced inorganic sulfur compounds as electron donors, was occasionally detected in column leachates, presumably because ferric iron dissolution of sulfide minerals would have generated these materials. Obligately (Leptospirillum spp, and Acidithiobacillus spp) and facultatively (Sb. thermosulfidooxidans) autotrophic acidophiles, and also obligately heterotrophic prokaryotes ( $A$. cryptum, Fp. acidiphilum) were present in ore leachates, the latter presumably using dissolved organic carbon (DOC) present as lysates and exudates of the primary producers. Even though At. ferrooxidans, At. ferridurans and Sb. thermosulfidooxidans oxidise both reduced inorganic sulfur compounds and ferrous iron, they might in the experimental conditions where ferrous iron was always present, be expected to have preferentially oxidized ferrous iron (generally the electron donor preferred by these bacteria). While ferric iron was reduced in the non-aerated column as a result of its oxidation of metal-containing sulfide minerals, microbial ferric iron reduction (coupled to the oxidation of sulfur and/or organic carbon) may have contributed to the net generation of ferrous iron in ore leachates. In previous bioleaching of Talvivaara ore carried out in aerated columns, Wakeman et al. (2008) reported that microbial populations changed radically with time and that this seemed to parallel changes in the chemistry of ore leachates. This contrasts greatly with the current work using an indirect bioleaching approach where microbial populations remained remarkably stable during the entire time course of the experiment. 


\section{Conclusions}

Base metals were successfully extracted from a polymetallic black schist sulfide ore by indirect leaching, using an acidic ferric iron lixiviant generated in a bioreactor containing a mixed culture of iron-oxidising acidophiles which was delivered to a non-aerated column containing $2.0-6.7 \mathrm{~mm}$ diameter ore particles. Results were comparable or superior to those reported for aerated columns, and no problem was encountered (as found elsewhere) with solution viscosity due to elevated concentrations of dissolved silicon. While the microbial populations in the lixiviant solutions and ore leachates showed some minor differences, in general they were quite similar to each other and dominated by iron-oxidising autotrophic bacteria; planktonic bacterial populations also stable over the time course of the experiment. The results of this work provide further support for the concept of deep in situ bioleaching of deep-buried base metal ore bodies.

\section{Acknowledgements}

This work was supported by the European Union Horizon 2020 project "BioMOre" (Grant agreement \# 642456)

\section{References}

Bedford, T., 2015. Talvivaara mine environmental disaster. EJOLT Factsheet No. 37.

Brierley, J.A., Brierley, C.L., 2001. Present and future commercial applications of biohydrometallurgy. Hydrometallurgy 59, 233-239.

Brierley, C.L., 2008. How will biomining be applied in future? T. Nonferr. Metal. Soc. 18, 13021310. 
Dopson, M., Halinen, A.-K., Rahunen, N., Bostrom, D., Sundkvist, J.-E., Riekkola-Vanhanen, M., Kaksonen, A.H., Puhakka, J.A., 2008. Silicate mineral dissolution during heap bioleaching. Biotechnol. Bioeng. 99, 811-820.

Halinen, A.-K., Rahunen, N., Kaksonen, A.H., Puhakka, J.A., 2009. Heap bioleaching of a complex sulfide ore Part I: Effect of $\mathrm{pH}$ on metal extraction and microbial composition in pH controlled columns. Hydrometallurgy 98, 92-100.

Johnson, D.B., Okibe, N., Hallberg, K.B., 2005. Differentiation and identification of ironoxidizing acidophilic bacteria using cultivation techniques and amplified ribosomal DNA restriction enzyme analysis. J. Microbiol. Methods 60, 299-313.

Johnson, D.B., Hallberg, K.B., 2007. Techniques for detecting and identifying acidophilic mineral-oxidising microorganisms, in: Rawlings D.E., Johnson D.B. (Eds.), Biomining. Springer-Verlag, Heidelberg, pp. 237-262.

Johnson, D.B., 2015. Biomining goes underground. Nature Geoscience 8, 165-166.

Kay, C.M., Rowe, O.F., Rocchetti, L., Coupland, K., Hallberg, K.B., Johnson, D.B., 2013. Evolution of microbial "streamer" growths in acidic, metal-contaminated stream draining an abandoned underground copper mine. Life 3, 189-210.

Loukola-Ruskeeniemi, K., Heino, T., 1996. Geochemistry and genesis of the black shale-hosted Ni-Cu-Zn deposit at Talvivaara, Finland. Econ. Geol. Bull. Soc. 91, 80-110.

Mudd, G.M., 2001. Critical review of acid in situ leach uranium mining: 1. USA and Australia. Environ. Geol. 41, 390-403.

Ňancucheo, I., Johnson, D.B., 2012. Selective removal of transition metals from acidic mine waters by novel consortia of acidophilic sulfidogenic bacteria. Microb. Biotechnol. 5, 3444. 
Ňancucheo, I., Rowe, O.F., Hedrich, S., Johnson, D.B., 2016. Solid and liquid media for isolating and cultivating acidophilic and acid-tolerant sulfate-reducing bacteria. FEMS Microbiol. Lett. 363, 1-6.

Puhakka, J., Tuovinen, O.H., 1986a. Microbiological leaching of sulfide minerals with different percolation regimes. Appl. Microbiol.Biot. 24, 144-148.

Puhakka, J., Tuovinen, O.H. 1986b. Biological leaching of sulfide minerals with the use of shake flask, aerated column, air-lift reactor, and percolation techniques. Acta Biotechnol. 6, 345-354.

Puhakka, J., Tuovinen, O.H., 1986c. Microbiological solubilization of metals from complex sulfide ore material in aerated column reactors. Acta Biotechnol. 6, 233-238.

Puhakka, J.A., Kaksonen, A.H., Riekkola-Vanhanen M., 2007. Heap Leaching of Black Schist, in: Rawlings D.E., Johnson D.B. (Eds.), Biomining. Springer-Verlag, Heidelberg, pp. 139151.

Rawlings, D.E., 2004. Microbially assisted dissolution of minerals and its use in the mining industry. Pure Appl. Chem. 76, 847-859.

Rawlings, D.E., Johnson, D.B., 2007. Biomining. Springer-Verlag, Heidelberg.

Riekkola-Vanhanen, M., Heimala, S., 1999. Study of the bioleaching of a nickel containing black-schist ore, in: Amils, R., Ballester, A. (Eds.), Biohydrometallurgy and the environment toward the mining of the $21^{\text {st }}$ century, part A. Elsevier. pp. 533-554.

Riekkola-Vanhanen, M., 2013. Talvivaara mining company - From a project to a mine. Miner. Eng. 48, 2-9.

Schippers, A., Sand, W., 1999. Bacterial leaching of metal sulfides proceeds by two indirect mechanisms via thiosulfate or via polysulfides and sulfur. Appl. Environ. Microb. 65, 319321. 
Stookey, L.L., 1970. Ferrozine---a new spectrophotometric reagent for iron. Anal. Chem. 42, 779-781.

Wakeman, K., Auvinen, H., Johnson, D.B., 2008. Microbiological and geochemical dynamics in simulated-heap leaching of a polymetallic sulfide ore. Biotechnol. Bioeng. 101, 739-750. 


\section{Abbreviations}

FIGB ferric iron-generating bioreactor

PLS pregnant leach solution

T-RFLP terminal restriction enzyme fragment length polymorphism

Keywords: bioreactors; deep in situ biomining; indirect bioleaching; polymetallic ores 
Table 1. Acidophilic prokaryotes used to inoculate the ferric iron-generating bioreactor (FIGB).

\begin{tabular}{ll}
\hline Mesophilic Acidophilic Bacteria & \\
\hline Leptospirillum (L.) ferrooxidans' $^{\top}$ & autotrophic $\mathrm{Fe}^{2+}$ oxidizer \\
Acidithiobacillus (At.) ferrooxidans & autotrophic $\mathrm{Fe}^{2+} / \mathrm{S}^{0}$ oxidizer \\
At. ferridurans' & autotrophic $\mathrm{Fe}^{2+} / \mathrm{S}^{0}$ oxidizer \\
At. ferrivorans strain CF27 & autotrophic $\mathrm{Fe}^{2+} / \mathrm{S}^{0}$ oxidizer \\
'At. ferriphilus' & autotrophic $\mathrm{Fe}^{2+} / \mathrm{S}^{0}$ oxidizer \\
At. thiooxidans' & autotrophic $\mathrm{S}^{0}$ oxidizer \\
Acidiphilium (A.) cryptum strain SJH & heterotrophic $\mathrm{S}^{0}$ oxidizer \\
'Acidibacillus (Ab.) ferrooxidans ${ }^{\top}$ & heterotrophic $\mathrm{Fe}^{2+}$ oxidizer \\
\hline Thermo-tolerant Acidophilic Bacteria & \\
\hline L. ferriphilum strain MT63 & autotrophic $\mathrm{Fe}^{2+}$ oxidizer \\
Sulfobacillus (Sb.) thermosulfidooxidans ${ }^{\top}$ & mixotrophic $\mathrm{Fe}^{2+} / \mathrm{S}^{0}$ oxidizer \\
At. caldus' & mixotrophic $\mathrm{S}^{0}$ oxidizer \\
'Ab. sulfurooxidans' & heterotrophic $\mathrm{Fe}^{2+} / \mathrm{S}^{0}$ oxidizer \\
\hline Thermo-tolerant Acidophilic Archaea & \\
\hline Ferroplasma (Fp.) acidiphilum strain BRGM4 & heterotrophic $\mathrm{Fe}^{2+}$ oxidizer \\
Acidiplasma sp. strain Fv & heterotrophic $\mathrm{Fe}^{2+}$ oxidizer \\
\hline
\end{tabular}


Table 2. Bacteria present in lixiviant (unshaded rows) and leachate (shaded rows) liquors during ferric iron leaching of the polymetallic Talvivaara ore, as detected by plating onto selective solid overlay media. (+) confirmed to be present; (-) not detected.

\begin{tabular}{|l|c|c|c|c|c|c|}
\hline \multirow{3}{*}{ Bacterium } & \multicolumn{7}{|c|}{ Sampling times (weeks) } \\
\cline { 2 - 7 } & 5 & 7 & 9 & 11 & 13 & 15 \\
\hline \multirow{2}{*}{ L. ferriphilum } & + & + & + & + & + & + \\
\cline { 2 - 8 } & + & + & + & + & + & + \\
\hline \multirow{2}{*}{ At. ferrooxidans } & + & + & + & + & + & + \\
\cline { 2 - 8 } & + & + & + & + & + & + \\
\hline \multirow{2}{*}{ At. ferridurans } & + & + & - & + & + & + \\
\cline { 2 - 8 } & + & + & + & + & + & + \\
\hline \multirow{2}{*}{ At. caldus } & + & - & + & + & + & - \\
\cline { 2 - 8 } & + & + & + & + & + & + \\
\hline Sb. thermo- & + & - & + & - & + & - \\
\hline sulfidooxidans & - & - & + & + & + & - \\
\hline
\end{tabular}



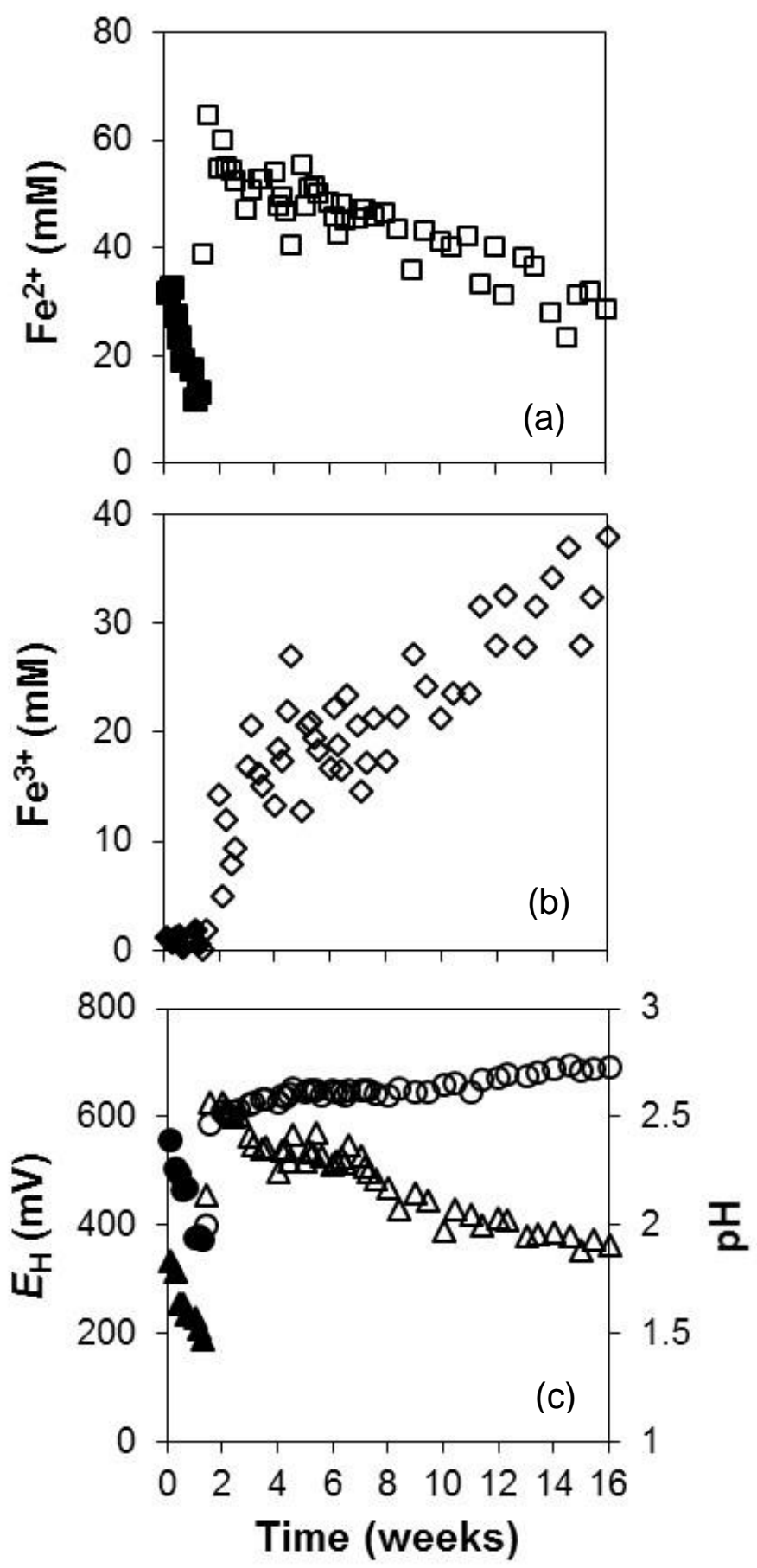

Fig. 1. Changes in concentrations of (a) ferrous iron ( $\square, \mathbf{a})$, (b) ferric iron $(\diamond, \diamond)$, and (c) pH $(\Delta, \boldsymbol{\Lambda})$ and redox potentials $(\bullet, 0)$ in leachate liquors from the Talvivaara ore column. Solid symbols show data from the acid leaching phase, and hollow symbols from the indirect bioleaching phase. 

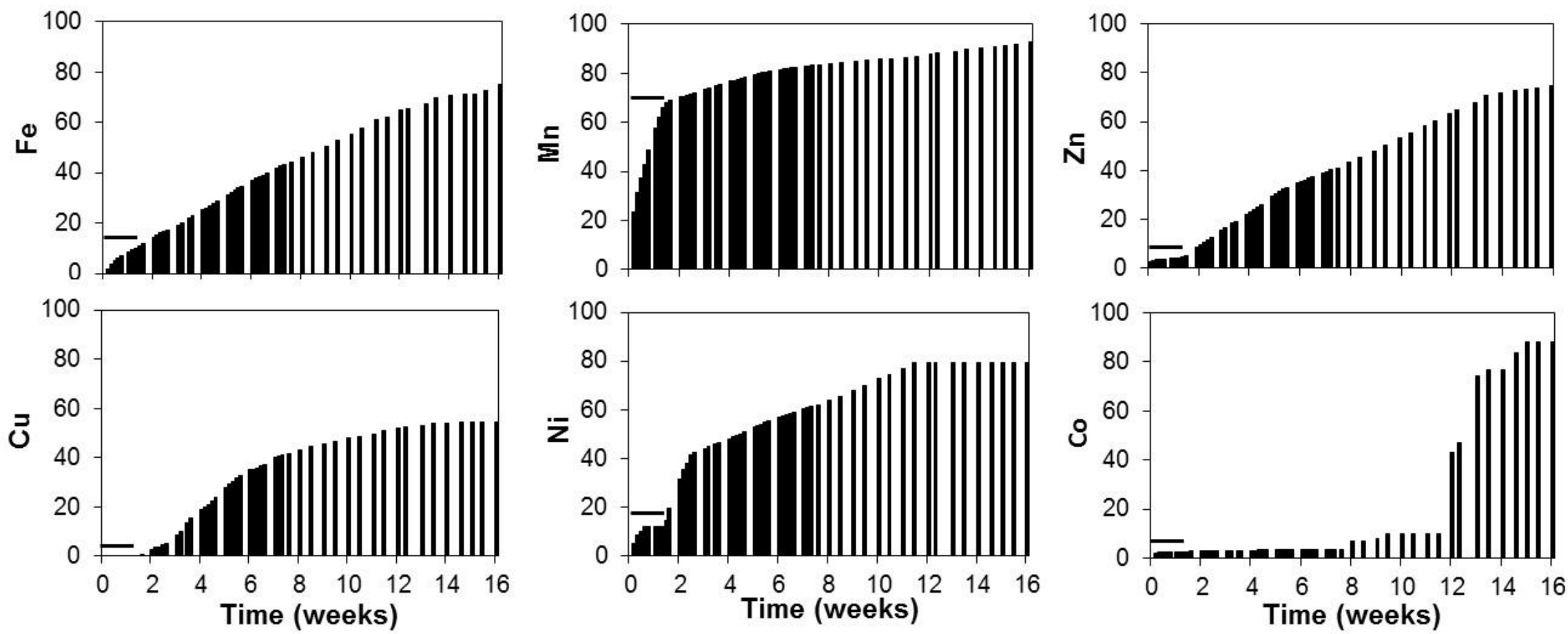

Fig. 2. Accumulated percentages of soluble iron, manganese, zinc, copper, nickel, and cobalt extracted from the Talvivaara ore in the flooded column reactor during sequential acid and ferric iron leaching. The bars in each of the graphs depict the acid leaching phase (day $0-10)$; from day 10 , the ore was subjected to indirect bioleaching with a ferric iron-rich lixiviant. 


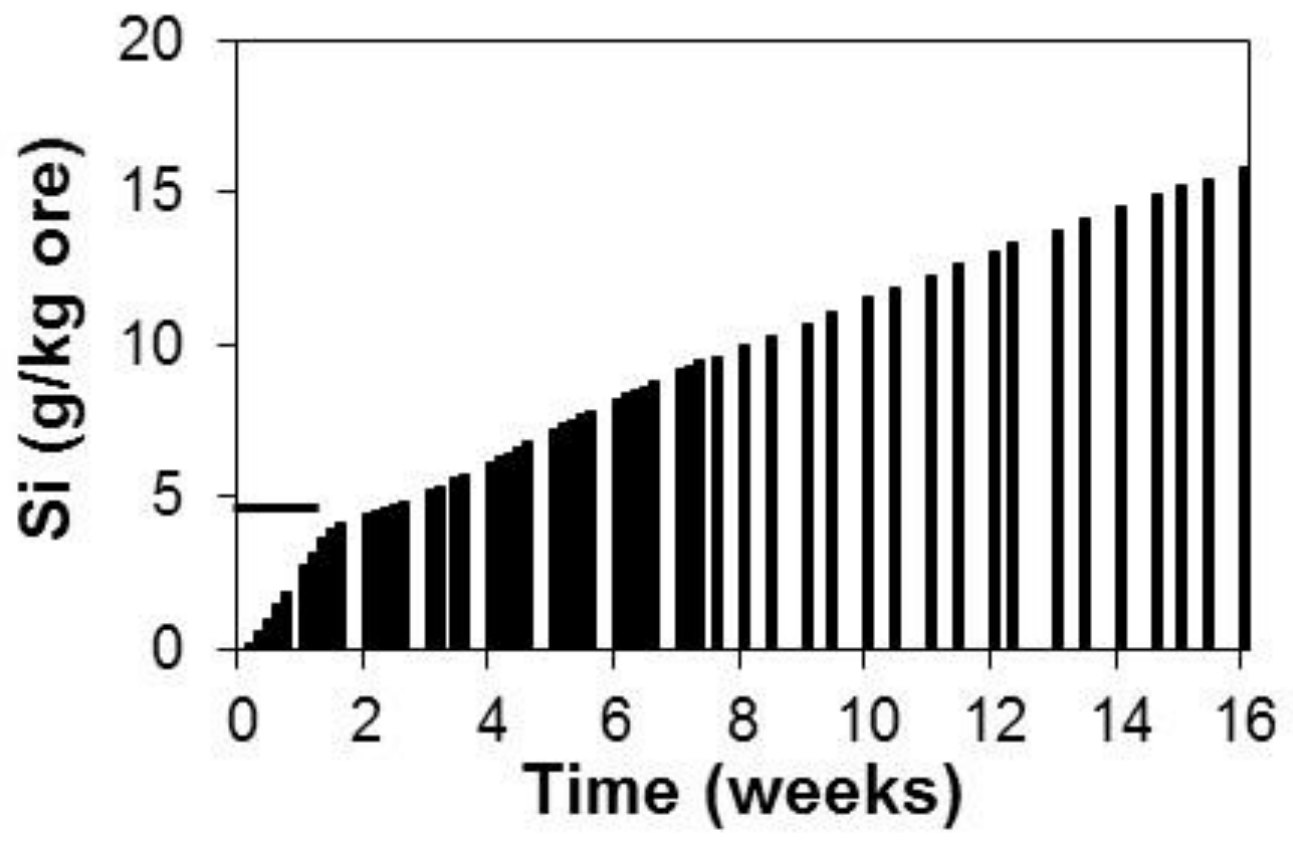

Fig. 3. Accumulated amount of silicon extracted from the Talvivaara ore in the flooded column reactor during sequential acid and ferric iron leaching. The bar depicts the acid leaching phase (days 0 -10). From day 10, the ore was subjected to indirect bioleaching with an acidic ferric iron-rich lixiviant. 


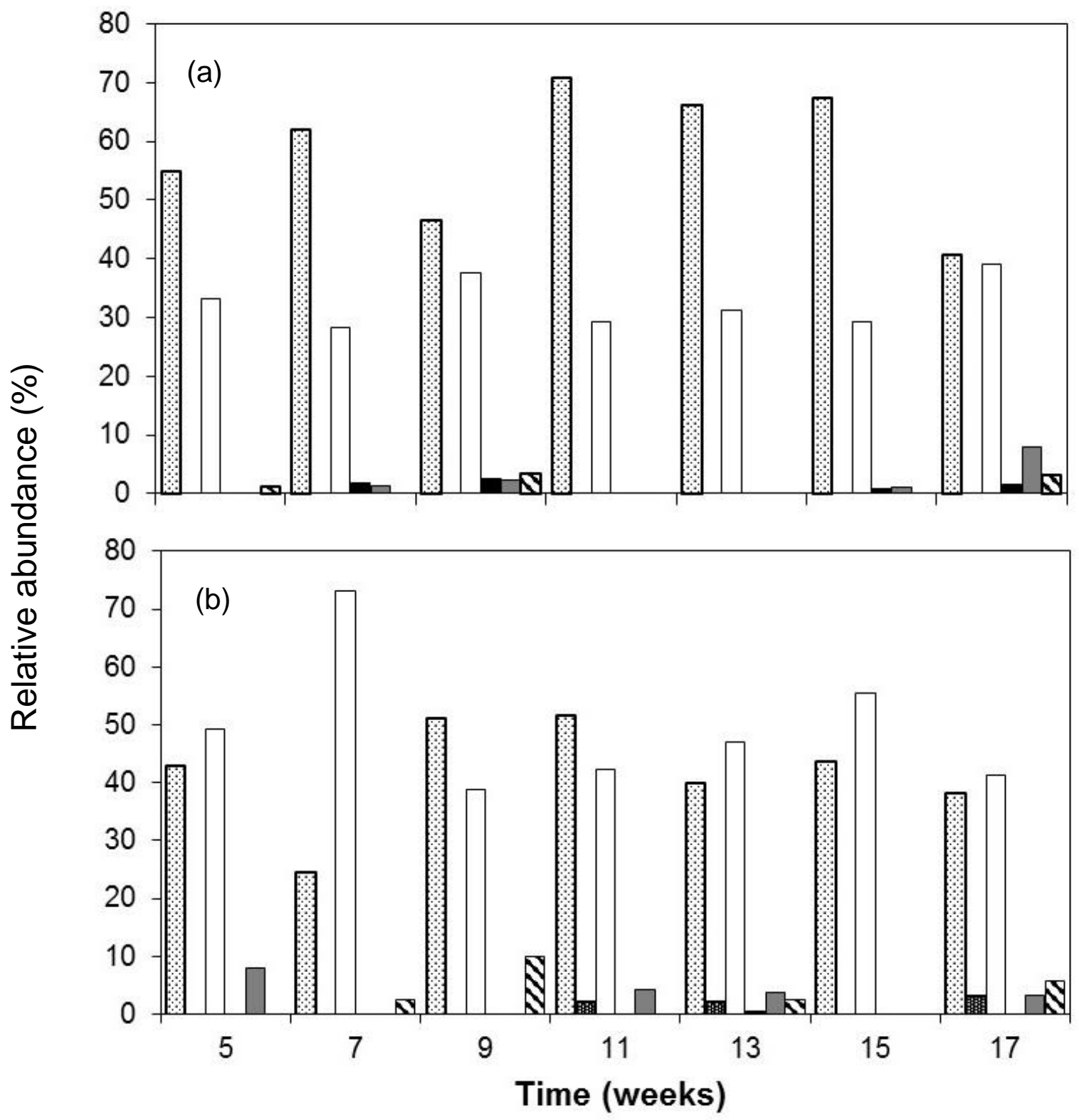

Fig. 4. Relative abundance of acidophilic bacteria in (a) the FIGB lixiviant, and (b) ore leachates, during indirect bioleaching of the polymetallic Talvivaara ore, as depicted by TRFLP analysis of amplified 16S rRNA genes digested with HaellI. Key: (3) L. ferriphilum,

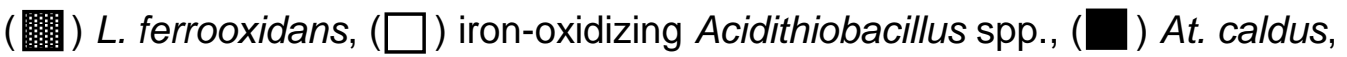

( $\square)$ Sb. thermosulfidooxidans, (\$) A. cryptum. 